\title{
Gingival ünite grefti ve trombositten zengin fibrin kullanılarak dişeti çekilmelerinin tedavisi: 3 Olgu sunumu
}

\author{
Sibel Kayaaltı Yüksek ${ }^{1}$, Emre Yaprak ${ }^{1}$
}

Selcuk Dent J, 2016; 3: 75-81

Başvuru Tarihi: 11 Ocak 2016 Yayına Kabul 16 Haziran 2016

\section{öz}

Gingival ünite grefti ve trombositten zengin fibrin kullanılarak dişeti çekilmelerinin tedavisi: 3 Olgu sunumu

Dişeti çekilmesi; dişeti kenarının, mine-sement birleşiminden apikale yer değiştirmesi ile kök yüzeyinin açığa çıkması olarak tanımlanır. Dişeti çekilmeleri, çeşitli periodontal plastik cerrahi yöntemlerle tedavi edilebilmektedir. Serbest dişeti grefti (SDG), özellikle yapışık dişeti miktarını artırmak adına yaygın olarak kullanılan ve öngörülebilir bir cerrahi yöntemdir. Bununla beraber, SDG ile yapıssık dișeti miktarı arttırılırken, aynı zamanda bell ölçülerde kök kapanmasının elde edilmesi de mümkün olmaktadır. Son dönemde SDG'inin, marjinal ve interdenta dişetini de içerecek şekilde modifiye edilmesi ile gingival ünite grefti (GÜG) geliştirilmiştir. Bu sayede daha başarılı kök kapanması elde edilebileceği literatürde belirtilmektir. Trombositten zengin fibrin (TZF), 2. nesil bir trombosit konsantrasyonudur ve lökositten ve trombositten zengin bir fibrin biyomateryalidir. Bu fibrin, büyüme faktörleri ve sitokinleri içerdiği için anjiogenezi ve yara iyileşmesini etkiler. Bu olgu raporunun amacı, mandibular anterior bölgede Miller II ve III dişeti çekilmeleri olan 3 hastanın, GÜG ve TZF ile tedavilerini ve bu tedavilerin sonuçlarını sunmaktır. Dişeti çekilme miktarı (DÇM), dişeti çekilme genişliği (DÇG), keratinize doku miktarı (KD), klinik ataçman seviyesi (KAS) ve sondlanabilir cep derinliği (CD) başlangıç ve post-operatif 6 . ayda değerlendirildi. Elde edilen sonuçlarına göre, Miller Sınıf II ve III dişeti çekilmelerinde, kök kapanması ve KDM arttıııması açısından GÜG başarıı bulunmuştur.

\section{ANAHTAR KELIMELER}

Dişeti çekilmesi, gingival ünite grefti, periodontal tedavi, trombositten zengin fibrin

Dişeti kenarı, periodontal olarak sağlıkı bireylerde klinik olarak mine-sement sınırında veya bu sınırın 1-2 $\mathrm{mm}$ koronalinde konumlanır. Dişeti çekilmesi ise dişeti kenarının apikale doğru hareket etmesi olarak tanımlanabilir (Zucchelli ve Mounssif 2015). Dişeti çekilmesinin temel nedenleri; dental plağa bağlı gelişen inflamatuar periodontal hastalık ve yanlış ağız bakımı tekniklerine bağlı olarak dişetinin maruz kaldığı mekanik travmadır. Bununla beraber, yaşlanma,

\begin{abstract}
Gingival unit graft and platelet-rich fibrin in the treatment of gingival recession: Report of 3 cases

Gingival recession (GR) can be defined as a shift of the gingival margin to a position apical to the cemento-enamel junction. GR can be treated with various periodontal plastic surgical procedures. Free gingival graft (FGG), is a widely used method which is particularly predictable for increasing keratinized tissue width(KT). While increasing of $K T$ can be achieved with FGG, and also root coverage (RC) within certain limits can be provided. Recently, FGG modified with the inclusion of marginal and papillary gingival tissue, the gingival unit graft (GUG) has been improved. Thus, it has been revealed in the literature, that $\mathrm{RC}$ can be obtained more successfully with GUG. Platelet-rich fibrin (PRF) is a second generation platelet concentrate and a leucocyte and plateletrich fibrin biomaterial. This fibrin which contains growth factors and cytokines effects angionesis and wound healing. The aim of the present case reports is to share the treatment and treatment results of 3 patients with 3 Miller's Class II and III recession defects on mandibular anterior teeth treated with GUG and PRF. Recession depth (RD), recession width, KT, clinical attachment level (CAL) and probing pocket depth (PPD) was measured at baseline and 6th month. According to the results of the present case reports, it can be concluded that GUG is usefull in Miller's Class II and III gingival recessions.
\end{abstract}

\section{KEYWORDS}

Gingival recession, gingival unit graft, periodontal treatment, platelet-rich fibrin

alveolar kemik dehisensi ve fenestrasyonu, yüksek frenulum ataçmanı, malpoze dişler, parmak, kalem emme gibi kişinin kronik alışkanlıkları, piercing ve sigara diğer risk faktörleri arasındadır (Susin ve ark. 2004, Zucchelli ve Mounssif 2015). Dişeti çekilmelerini tedavi etmek adına, çeşitli periodontal plastik cerrahi yöntemlere başvurulmaktadır. Bu kapsamda; saplı yumuşak doku greftleri (laterale pozisyone flep, çift papilla flebi, koronale pozisyone

\footnotetext{
${ }^{1}$ Kocaeli Üniversitesi Diş Hekimliği Fakültesi Periodontoloji Anabilim Dalı, Kocaeli
} 
flep, semilunar flep), serbest yumuşak doku greftleri (serbest dişeti grefti, subepitelyal bağ dokusu grefti) veya rejeneratif teknikler kullanılmaktadır (Bouchard ve Malet 2001).

Serbest dişeti grefti (SDG), Björn tarafından tanımlanmıştır ve yapışık dişeti genişliğinin arttırıması için kullanılmıştır. SDG, keratinize dişeti miktarının arttırıması, kök yüzeyinin kapatıması, yüksek frenulum etkisinin kaldırıması ve hastanın oral hijyenini rahatlıkla sağlayabileceği bir doku konturu oluşturulması amacı ile kullanılabilir (Sullivan ve Atkins 1968). Yetersiz yapışı dişeti genişliği ile birlikte dişeti çekilmelerinin tedavisinde veya kök yüzeyinin örtülmesini takiben subgingival bir restorasyon planlanıyorsa SDG en iyi tedavi seçeneği olarak düşünebilir (Camargo ve ark. 2001). Literatürde, serbest dişeti grefti ile ortalama kök kapanma yüzdesi \%11-100 arasında değişmektedir. Bu varyasyonlar, gingival lezyonun şiddetindeki farklııklara ve cerrahi tekniklere bağlı olabilir (Zucchelli ve Mounssif 2015). Bazı yazarlar ise, açığa çıkmış avasküler kök yüzeyine yerleştirilen greft dokusunda, yeterli derecede kan desteği sağlanamadığı ve bunun sonucunda parsiyel nekroz geliştiği için kök kapama tedavisinde SDG'ini düşük derecede öngörülebilir bir yöntem olarak bildirmiştir (Bernimoulin ve ark. 1975, Raetzke 1985). SDG ile kök kapanması başarısını arttırmak amacıyla, kök yüzeyine kimyasal ajanların (sitrik asit vb.) uygulanması, greft kalınlığının arttırıması, kök konveksliğinin azaltılması, farklı sütur teknikleri ile greft adaptasyonunun ve stabilizasyonunun arttırılması gibi modifikasyonlar uygulanmıştır (Miller 1985). Son dönem çalışmalarda donör greftin, vasküler desteği zengin olan spesifik bölgeden elde edilmesi ile greftin canlılığının korunması ve istenilen kök kapanması sağlanabilineceği düşüncesi ile serbest dişeti grefti (SDG) marjinal ve interdental dişetini içerecek şekilde modifiye edilmiş ve gingival ünite grefti (GÜG) olarak tanımlanmıştır. Böylece, greftin vasküler desteğinin arttırıması sağlanabilir. Ayrıca alıcı sahanın damarsal konfigürasyonuna sayı ve boyut olarak daha yakın bir greft elde edilebilir. Aynı zamanda, marjinal dişetini içeren greft, alıcı saha ile daha iyi renk uyumu sağlayarak estetik olarak daha başarılı sonuçlar gösterebilir. Post-operatif dönemde ise, gingival ünite greftinin, palatinal artere uzak olması ile post-operatif kanama komplikasyonu riski azalır (Allen 2004, Kuru ve Yıldırım 2013).

Trombositten zengin fibrin (TZF), dişhekimliğinde sıklıkla kullanılmaktadır. TZF, yapısında bol miktarda trombosit, lökosit, sitokin ve dolaşımdaki kök hücreleri içeren tetramolekül yapısında polimerize fibrin matriksinden oluşmuştur. TZF, optimal iyileşme için gerekli olan parametreleri içerdiğinden, yara iyileşmesi üzerine olumlu etkileri bulunmaktadır. TZF, fizyolojik iyileşme sürecini hızlandıran bir biyomateryal olarak değerlendirilebilir (Choukroun ve ark. 2006).
$\mathrm{Bu}$ olgu sunumunda, mandibular anterior bölgede lokalize dişeti çekilmesi olan 3 hastanın kök kapama tedavisinde GÜG'nin kullanıması ve alıcı yatağa yerleştirilen greftin ve verici bölgenin TZF ile kapatımasının 6 aylık takip sonuçları sunulmaktadır.

\section{OLGU SUNUMU}

\section{Olgu 1}

Sistemik olarak sağlıkı olan 18 yaşındaki kadın hasta Kocaeli Üniversitesi Diş Hekimliği Fakültesi, Periodontoloji Anabilim Dalı'na dişeti çekilmesi şikayeti ile başvurdu. Yapılan klinik ve radyolojik muayenesinde hastanın gingivitis hastası olduğu ve 41 numaralı dişinde Miller II dişeti çekilmesi olduğu görüldü (Resim 1A). Öncelikle hastaya ağız hijyen eğitimi verildi. Başlangıç olarak plak indeksi, gingival indeks ve periodontal cep derinliği ölçüldü. Diştaşı temizliği ve kök yüzeyi düzleştirme işleminin ardından 41 numaralı dişe kök kapama tedavisi için GÜG ile periodontal cerrahi planlandı. Operasyondan önce ilgili dişte 2 mm'yi aşan cep derinliği olmamasına ve plak ve gingival indeks skorlarının sıfır değerine yakın olmasına dikkat edildi. Operasyondan hemen önce dişeti çekilme miktarı (mine-sement sınırı ile dişeti kenarı arasındaki mesafe), dişeti çekilmesinin genişliği (minesement sınırında horizontal yönde çekilmenin genişliği), keratinize doku miktarı (dişeti kenarı ile mukogingival birleşim arasındaki mesafe), klinik ataçman seviyesi ve sondlanabilir cep derinliği kayıt altına alındı (Tablo 1). Verici alan ve greftin alıcı yatağa yerleştirilmesinden sonra TZF ile örtülmesi planlandı.

Periodontal cerrahiden önce, TZF için hastadan standart $10 \mathrm{~mL}$ 'lik antikoagülansız kan tüpleri (Advanced PRF $10 \mathrm{~mL}$ tüp) ile $30 \mathrm{ml}$ venöz kan alındı. TZF için kan tüpleri hızlı bir şekilde santrifuj cihazına (A-PRF 12) (Advanced PRF, Process, Nice, France) yerleştirildi ve 1500 rpm'de 14 dakika santrifüj edildi (Ghanati ve ark. 2014). İlgili diş ve sağ damak bölgesine lokal infiltrasyon anestezisi yapıldı. Konvansiyonel serbest dişeti grefti ile aynı şekilde alıcı yatak hazırlandı (Resim 1C). 41 numaralı dişin minesement sınırından mezial ve distale uzanan iki yatay insizyon yapıldı. ilgili dişte bu yatay insizyonlarla birleşen sulkular insizyon yapıldı. Mukogingival birleşimi 3-4 mm aşacak şekilde apikale uzanan iki dikey insizyonla, trapezoidal şeklinde (tabanı geniş) alıcı bölgenin insizyonu tamamlandı. 15 numara bistüri (Beybi Plastik Fabrikası Sanayi A.Ş., İstanbul) ile yarım kalınlık flep kaldırıdı. Flep 3/0 ipek sütur (3/0, İpek, Doğsan A.Ş., Trabzon, Türkiye) ile alıcı bölgenin apikalinde periosta dikildi. Papiller dişeti deepitelize edildi. Alıcı yatakta, hareketsiz bağ dokusu ve periost bırakıldı. Kas ve gevşek bağ dokusu fibrilleri kesilip uzaklaştıııldı. Kök yüzeyi düzleştirilmesi periodontal küretlerle yapıldı. Alıcı bölgeye yerleștirilen alüminyum 

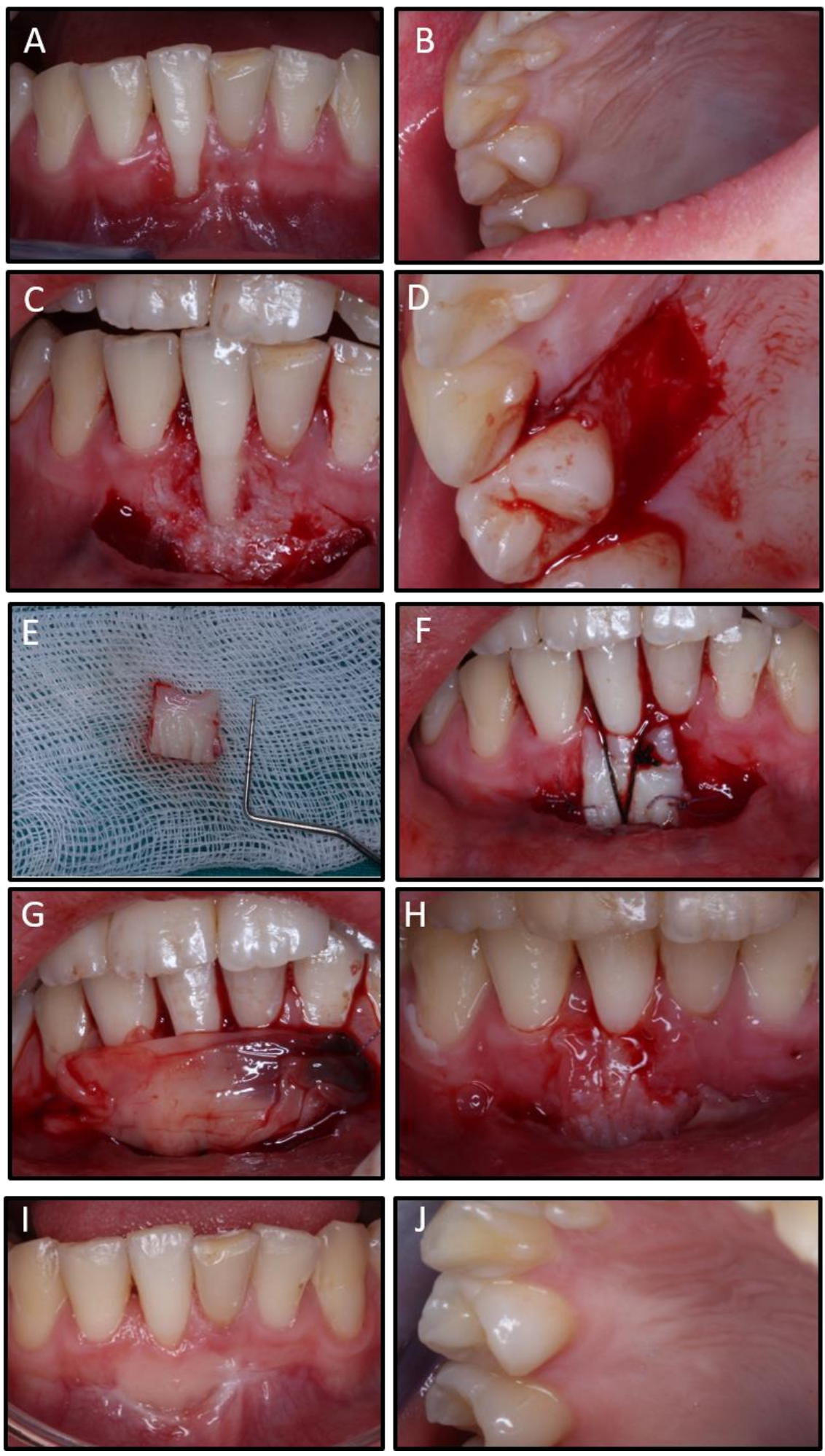

Resim 1.

A ) Birinci olgunun başlangıç ağız içi görüntüsü

F ) Greftin alıcı bölgeye yerleştirilmesi

B ) Birinci olgunun başlangıç verici alan görüntüsü

G ) Greftin PRF ile kapatılması

C) Alıcı alan

D ) Donör alan

E ) Elde edilen GÜG

H ) Operasyon sonrası 1. hafta alıcı alan görüntüsü

I ) 6. ayda alıcı alan görüntüsü

J ) 6. ayda verici alan görüntüsü 
folyo ile alınacak greftin boyutları belirlendi. Alıcı bölgeye yerleştirilen alüminyum folyo rehberliğinde alıcı bölgenin şekil ve boyutuna uygun greft alınmasına dikkat edildi. Sağ maksiller 2. premolar dişin palatinalinde marjinal gingival dokuyu içerecek şekilde sulkular insizyon ve distal ve meziyal papilleri de içerecek şekilde iki vertikal insizyon yapılarak gingival ünite grefti elde edildi (Resim 1D, Resim 1E). Elde edilen greft alıcı bölgeye mine-sement sınırında yerleştirildi ve alıcı yatağa gergin olacak şekilde 5/0 vikril (5/0, Vicryl, Ethicon, Johnson \& Johnson, StStevens-Woluwe, Belgium) ve $3 / 0$ ipek sütur ile horizontal matris ve basit süturlarla sabitlendi (Resim 1F). Donör alan ve greft cerrahiden önce hastadan kan alınarak elde edilen TZF ile örtüldü. TZF' nin sabitlenmesinde $3 / 0$ ipek ile çapraz askı süturlar ve basit süturlar kullanıldı (Resim 1G).

Post-operatif bakım için hastaya \% 0,2'lik klorheksidin diglukonat (Klorhex Gargara, Drogsan A.Ş., Ankara, Türkiye) ile 3 hafta boyunca, günde 2 kez kullanılmak üzere gargara reçete edildi. Ayrıca, 1 hafta boyunca, günde 2 defa kullanılmak üzere antibiyotik (Amoksisiklin + klavulanik asit $1000 \mathrm{mg}$ film tablet) (Augmentin BID, Abdi İbrahim İlaç Sanayi ve Ticaret A.Ş., İstanbul Türkiye) ve analjezik (Flurbiprofen $100 \mathrm{mg}$ film tablet)
İlaç Sanayi ve Ticaret A.Ş., İstanbul Türkiye) ve analjezik (Flurbiprofen $100 \mathrm{mg}$ film tablet) (Majezik, Sanovel ilaç A.Ş., İstanbul, Türkiye) reçete edildi. 2 hafta boyunca hastalardan fırçalama yapılmaması istendi ve hastalar sert çiğnemekten kaçınılması konusunda uyarıldı. Hasta post-operatif düzenli kontrollere çağrılarak iyileşme süreci takip edildi (Resim 1I, Resim 1J). 6. ay sonunda ilgili dişlere ait dişeti çekilme miktarı, dişetinin çekilme genişliği ve keratinize doku miktarı, klinik ataçman seviyesi ve sondlanabilir cep derinliği değerlendirildi (Tablo 1).

\section{Olgu 2}

Sistemik olarak sağlıklı olan 21 yaşındaki kadın hasta Kocaeli Üniversitesi Diş Hekimliği Fakültesi, Periodontoloji Anabilim Dalı'na dişeti çekilmesi şikayeti ile başvurdu. Hastanın yapılan klinik ve radyolojik muayenesinde hastanın gingivitis hastası olduğu ve 31 numaralı dişinde Miller III dişeti çekilmesi olduğu görüldü (Resim 2A). Tedavi planı, cerrahi işlemler, postoperatif dönem birinci olgu ile aynı olacak şekilde yapıldı. Başlangıç periodontal tedavileri tamamlandıktan sonra 31 numaralı dişe GÜG ve TZF kullanılarak kök kapama tedavisi yapıldı. (Resim 2B, Resim 2C). 6 ay sonra hasta tekrar değerlendirildi (Resim 2D, Resim 2E).
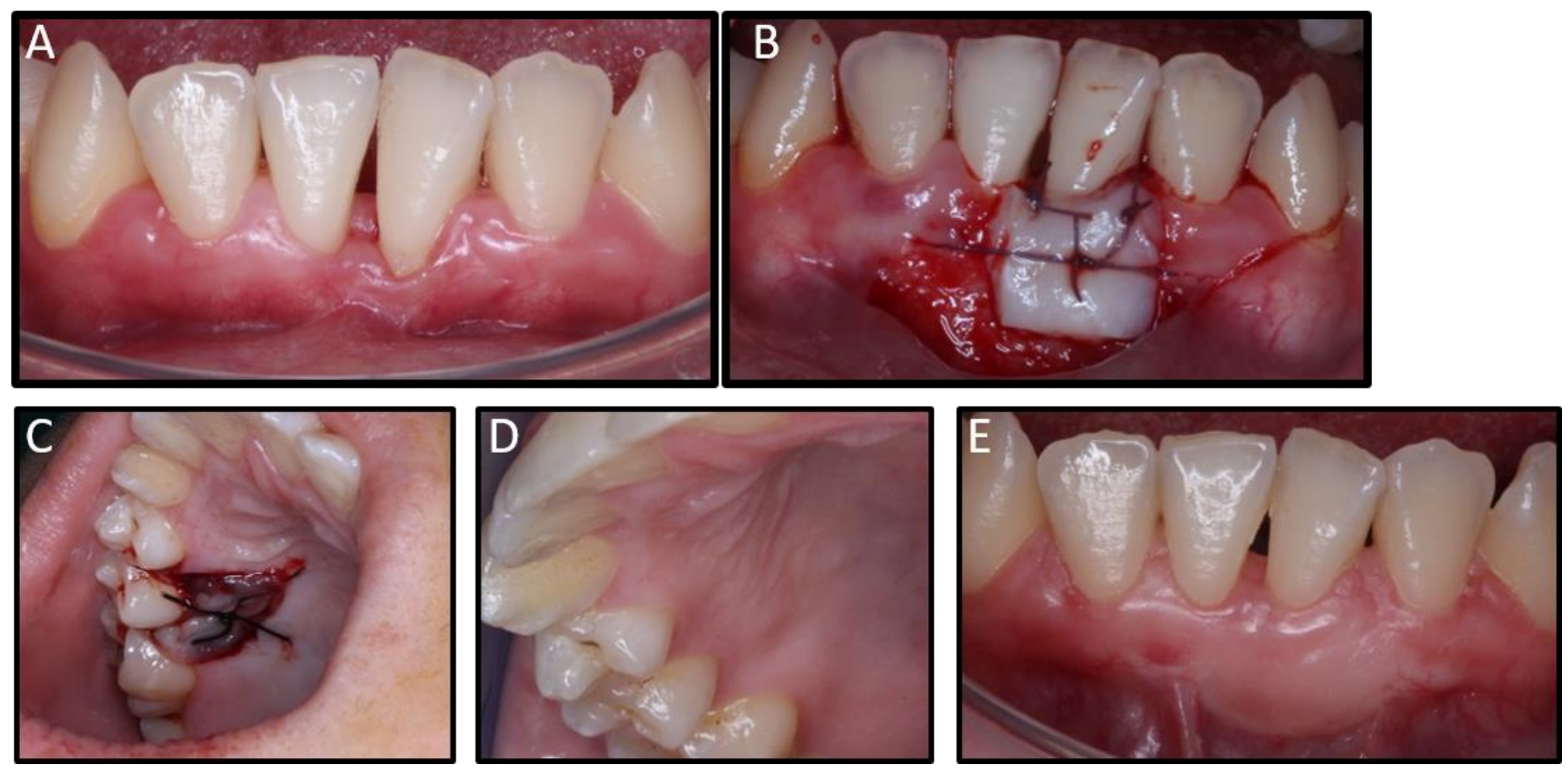

Resim 2.
A ) İkinci olgunun başlangıç ağız içi görüntüsü
B ) Greftin alıcı bölgeye yerleştirilmesi
C) Verici alanın PRF ile kapatılması
D ) 6. ayda verici alan görüntüsü
E ) 6. ayda alıcı alan görüntüsü 


\section{Olgu 3}

Sistemik olarak sağlıklı olan 17 yaşındaki kadın hasta Kocaeli Üniversitesi Diş Hekimliği Fakültesi, Periodontoloji Anabilim Dalı'na dişeti çekilmesi şikayeti ile bașvuran hastanın 31 numarasındaki
Miller III dişeti çekilmesi (Resim 3A) tedavi planı, cerrahi işlemler, post-operatif dönem birinci ve ikinci olgu ile aynı olacak şekilde yapıldı. (Resim 3B, Resim $3 \mathrm{C)}$.
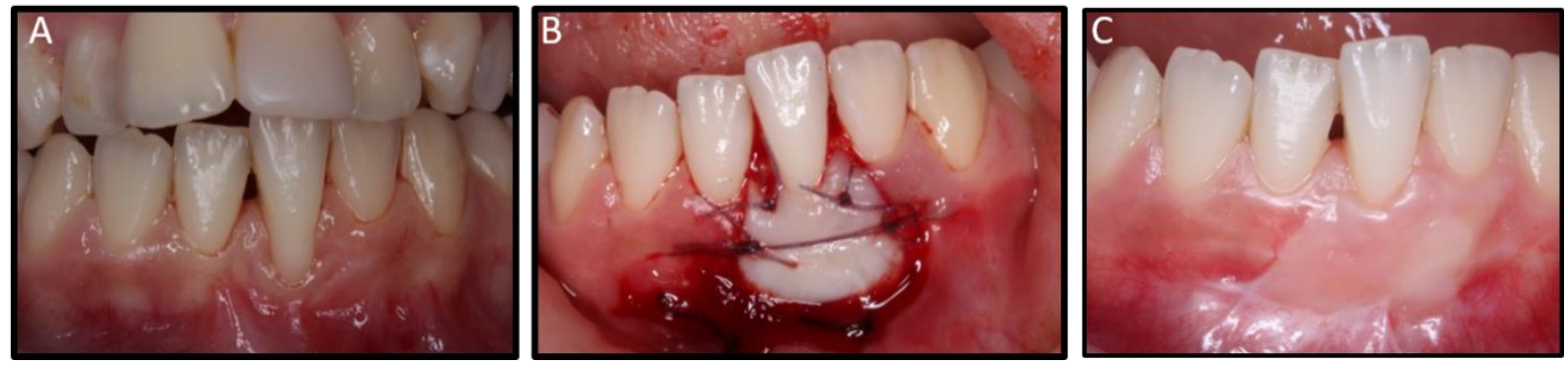

Resim 3.

A ) Üçüncü olgunun başlangıç ağız içi görüntüsü

B ) Greftin alıcı bölgeye yerleştirilmesi

C ) 6. ayda alıcı alan görüntüsü

\section{TARTIŞMA}

Serbest dişeti ve papiller dokuyu içeren sağlıklı dişetinin suprakrestal bölümü, spesifik vaskülariteye sahiptir. GÜG ile greftin kan desteği artırlarak, avasküler kök yüzeyinde greftin beslenmesinin artması sağlanabilir. Greftte parsiyel nekroz riski azalır ve başarılı kök kapanması sonuçları elde edilebilir. GÜG, kök kapama tedavisinde uygulanan güncel bir tekniktir. GÜG ilk defa 2004 yılında Allen tarafından rapor edilmiştir. İlgili raporda, amalgam dövmesi bulunan üst lateral dişe ait pigmente dişeti dokusu eksize edilerek uzaklaştırımıştır. Maksiller premolar dişlerden gingivektomi insizyonu ile alınan GÜG bölgeye adapte edilmiştir. Post-operatif 2. yılda dişetinin konumu ve rengi açısından başarılı sonuç alınmıştır. Rekürens ise görülmemiştir. Ayrıca, Miller I lokalize dişeti çekilmesi bulunan alt çene keser dişin GÜG ile ogmentasyonu yapılmıştır. Post-operatif 3 . ayda tam kök kapanması sağlandığı görülmüştür (Allen 2004).

Kuru ve Yıldırım lokalize dişeti çekilmelerinde GÜG kullanımını randomize, kontrollü klinik bir çalışma ile sunmuştur. 17 hastadan oluşan çalışmada Miller I ve II dişeti çekilmeleri çalışmaya dahil edilmiştir. Sekiz hastadan oluşan test grubu GÜG ile, 9 hastadan oluşan kontrol grubu SDG ile tedavi edilmiştir. Sekiz ay sonra dişeti çekilme miktarındaki azalma, keratinize doku kazancı, klinik ataçman seviyesi kazancı, ortalama kök kapanma miktarı açısından değerlendirildiğinde GÜG ile istatiksel olarak anlamlı derecede daha iyi sonuçlar alınmıştır. GÜG ile ortalama \%91.62 kök kapanması elde edilmiştir (Kuru ve Yıldırım 2013).

2015 yllında, Yıldırım ve Kuru Miller III dişeti çekilmelerinde GÜG kullanmışlardır. Miller III dişeti çekilmesi olan iki hastayı GÜG ve SDG ile tedavi ederek, klinik sonuçları karşılaştırmışlardır. GÜG ile tedavi edilen çekilmede \%80, SDG ile \%50 defekt kapanması sağlanmıştır. Dişeti çekilme miktarındaki azalma, keratinize doku kazancı, klinik ataçman seviyesi kazancı ve ortalama kök kapanma miktarı açısından GÜG daha başarılı bulunmuştur (Yıldırım ve Kuru 2015). Bu olgu raporundan elde edilen sonuçlar da bu çalışmalar ile uyumlu bulunmuştur. Olgularımızda, Miller II ve III dişeti çekilmelerinde GÜG kullanıması ile 6 ay sonra kök kapanmasında ve keratinize doku artışında başarılı sonuçlar elde edilmiştir (Tablo 1).

Bakteriyel biyofilmin gelişmesini sağlayacak lokal ISI ve nem artışına sebep olabileceğinden donör saha ve greft üzerini kapatmak için periodontal pat kullanımın yara iyileşmesine olumsuz etkileri olabilmektedir (Bourne 1981). TZF'in ise, yumuşak doku iyileşmesini hızlandırıcı etkisi bulunmaktadır ve çeşitli periodontal cerrahi uygulamalarında sıklıkla kullanılmaktadır. TZF, yumuşak doku maturasyonu ve iyileşmenin 3 önemli basamağı olan anjiogenez, immün kontrol ve epitelyal kapanmanın gelișimini etkili bir șekilde destekler. 
Yaralanmıs dokuların TZF ile kapatılması epitel hücrelerinin ve fibroblastların metabolizmalarını etkiler (Choukroun ve ark. 2006). Olgularımızda, antikoagülan, anti-infektif ve yara iyileşmesine olan etkileri sebebi ile donör ve alıcı saha TZF ile kapatılmıştır ve 3 olguda da yara kapanması üzerine olumlu sonuçlar alınmıstır.

\section{SONUÇ}

$\mathrm{Bu}$ olgu raporundan elde edilen sonuçlar dahilinde, Miller II ve III dişeti çekilmelerinde kök kapama tedavisinde GÜG kullanılması başarılı bulunmuştur. Elde edilen sonuçlar, hem hekim hem de hasta açısından memnun edicidir. Ayrıca GÜG, greftin palatinal artere uzak olması ve post-operatif kanama riskini azaltması açısından avantajlı olabileceği düşünülmektedir.

\section{Tablo 1.}

Başlangıç ve post-operatif 6 . aydaki periodontal ölçümler

\begin{tabular}{lcccccc} 
& & BAŞLANGIÇ & & \multicolumn{3}{c}{ TEDAVi SONRASI (6.AY) } \\
\hline & Olgu 1 & Olgu 2 & Olgu 3 & Olgu 1 & Olgu 2 & Olgu 3 \\
\hline DÇM & 5 & 2 & 3,5 & 0,5 & 0 & 1 \\
\hline DÇG & 2,5 & 3 & 3 & 1 & 0 & 2 \\
\hline KDM & 0 & 1 & 1 & 7 & 6 & 6 \\
\hline CD (mid-bukkal) & 1 & 1 & 1 & 1 & 2 & 1 \\
\hline KAS (mid-bukkal) & 6 & 3 & 4,5 & 1,5 & 0 & 2 \\
\hline $\begin{array}{l}\text { DÇM: Dişeti çekilme miktarı (mm) } \\
\text { DÇG: Dişeti çekilme genişliği (mm) } \\
\text { KDM (mm): Keratinize doku miktarı } \\
\text { CD: Sondlanabilir cep derinliği (mm) } \\
\text { KAS: Klinik ataçman seviyesi (mm) }\end{array}$ & & & & & \\
\hline
\end{tabular}




\section{KAYNAKLAR}

Allen AL, 2004. Use of the gingival unit transfer in soft tissue grafting: report of three cases. Int Periodontics Restorative Dent, 24, 165-175.

Björn H, 1963. Free Transplantation of Gingiva Propria. Sven Tandlak Tidskr, 22, 684-689.

Bernimoulin JP, Luscher B, Muhlemann HR,1975 Coronally repositioned periodontal flap. Clinical evaluation after one year. J Clin Periodontol, 2, 1-13.

Bourne GH. Nutrition and wound healing, 1981.Tissue repair and regeneration. Amsterdam: Elsevier/ North Holland Biomedical Press, 212-241.

Bouchard P, Malet J, Borghetti A, 2001. Decisionmaking in aesthetics: root coverage revisited. Periodontol 2000, 27,97-20.

Camargo PM, Melnick PR, Kenney EB, 2001. The use of free gingival grafts for aesthetic purposes. Periodontol 2000, 27,72-96.

Choukroun J, Diss A, Simonpieri A, Girard MO, Schoeffler C, Dohan SL, Dohan AJ, Mouhyi J, Dohan DM, 2006. Platelet-rich fibrin (PRF): a secondgeneration platelet concentrate. Part IV: clinical effects on tissue healing. Oral Surg Oral Med Oral Pathol Oral Radiol Endod 101(3),56-60.

Ghanaati S, Booms P, Orlowska A, Kubesch A, Lorenz J, Rutkowski J, Landes C, Sader R, Kirkpatrick C, Choukroun J, 2014. Advanced plateletrich fibrin: a new concept for cell-based tissue engineering by means of inflammatory cells. $\mathrm{J}$ Oral Implantol, 40(6),679-689.

Kuru B, Yildirim S, 2013. Treatment of localized gingival recessions using gingival unit grafts: a randomized controlled clinical trial. J Periodontol, 84,41-50.

Miller PD, Jr, 1985. A classification of marginal tissue recession. Int J Periodontics Restorative Dent, 5,813.

Raetzke PB, 1985. Covering localized areas of root exposure employing the "envelope" technique. J Periodontol, 56,397-402.

Susin C, Haas AN, Oppermann RV, Haugejorden O, Albandar JM, 2004. Gingival recession: epidemiology and risk indicators in a representative urban Brazilian population. J Periodontol, 75:13771386.

Sullivan HC, Atkins JH, 1968. Free autogenous gingival grafts. I. Principles of successful grafting. Periodontics, 6:121-129.
Yildirim S, Kuru B, 2015. Gingival unit transfer using in the Miller III recession defect treatment. World J Clin Cases, 3,199-203.

Zucchelli G, Mounssif I, 2015. Periodontal plastic surgery. Periodontol 2000, 68,333-368.

Yazışma Adresi:

Emre YAPRAK, DDS, PhD

Kocaeli Üniversitesi

Diş Hekimliği Fakültesi

Periodontoloji Anabilim Dalı, Kocaeli

Tel : +902623442222

Faks : +90 2623442109

E-mail: dt_emreyaprak@hotmail.com 